\title{
Relevansi Gagasan Pencalonan Presiden dan Wakil Presiden Jalur Perseorangan terhadap Prinsip Negara Hukum dan Demokrasi
}

\author{
Yuniar Riza Hakiki \\ Program Magister Ilmu Hukum Universitas Islam Indonesia \\ yuniarrizahakiki@gmail.com
}

\begin{abstract}
This article discusses the relevance of the for nominating the President and Vice President through the individual based on the principles of rule of law and democracy in Indonesia. Article 6A paragraph (2) of the 1945 Constitution of the Republic of Indonesia restricts the nomination of the President and Vice President of the Republic of Indonesia in a way that it can only be proposedby political parties or a combination of political parties. In other words, it limits individual candidate. As a country that adheres to the principles of the rule of law and democracy, various channels of democracy as a means of actively participating in politics must naturally be open widely. Therefore, the recruitment system for the positions of President and Vice President needs to be redesigned in line with principles of rule of law and democracy in Indonesia. This article concludes that the idea of the for nominating the President and Vice President through the individual channels is by the principles of the rule of law and democracy, which is at least proven by the four arguments based on of the rule of law principles and democracy. First, guaranteeing the constitutional rights of citizens in political field. Second, guaranteeingself-actualization of citizens in political life independently (without being mobilized). Third, guaranteeing political recruitment to fill positions holding the state openly. Fourth, guarantee that the constitutional-based government is accommodative and remains organized according to law.
\end{abstract}

Keywords: filling the President and Vice President; individual candidate; rule of law principles; democracy. 


\section{Abstrak}

Artikel ini membahas relevansi pencalonan Presiden dan Wakil Presiden melalui jalur perseorangan atas dasar prinsip negara hukum dan demokrasi di Indonesia. Pasal 6A ayat (2) UUD NRI 1945 membatasi pencalonan Presiden dan Wakil Presiden Republik Indonesia yaitu hanya dapat diusulkan oleh partai politik atau gabungan partai politik. Hal itu menutup kesempatan pencalonan dari jalur perseorangan. Sebagai negara yang menganut prinsip negara hukum dan demokrasi, berbagai kanal demokrasi sebagai sarana berpartisipasi politik secara aktif dalam pemerintahan tentu harus terbuka lebar. Oleh karenanya, rekrutmen jabatan Presiden dan Wakil Presiden ini perlu didesain ulang agar lebih akomodatif dan selaras dengan prinsip negara hukum dan demokrasi Indonesia. Artikel ini menyimpulkan bahwa gagasan pencalonan Presiden dan Wakil Presiden melalui jalur perseorangan berkesesuaian dengan prinsip negara hukum dan demokrasi, yang setidaknya dibuktikan dengan empat argumen yang merujuk prinsip negara hukum dan demokrasi. Pertama, menjamin hak konstitusional warga negara di bidang politik. Kedua, menjamin aktualisasi diri warga negara dalam kehidupan politik secara mandiri (tanpa digerakkan). Ketiga, menjamin rekrutmen politik untuk mengisi jabatan-jabatan penyelenggaraan negara secara terbuka. Keempat, menjamin pemerintahan yang berdasarkan konstitusi secara akomodatif berdasarkan hukum.

Kata kunci: pengisian jabatan Presiden dan Wakil Presiden; calon perseorangan; prinsip negara hukum; demokrasi.

\section{A. Pendahuluan}

Artikel ini membahas relevansi gagasan pencalonan Presiden dan Wakil Presiden melalui jalur perseorangan terhadap prinsip negara hukum dan demokrasi di Indonesia. Pembahasan demikian menjadi perlu karena dua hal. Pertama, jalur rekrutmen pasangan calon Presiden dan Wakil Presiden hingga saat ini hanya tersedia melalui partai politik (parpol), dan karenanya perlu digagas kemungkinan jalur non parpol (jalur perseorangan). Kedua, dalam negara hukum yang demokratis, ketersediaan jalur-jalur pemilihan jabatan negara yang tidak dimonopoli oleh pihak tertentu, dalam hal ini parpol, sesungguhnya diperlukan. Gagasan yang menawarkan agar jalur 
perseorangan dibuka dalam pencalonan Presiden dan Wakli Presiden, pada dasarnya untuk meneguhkan prinsip negara hukum yang demokratis.

Berkenaan dengan hal tersebut, pilihan meletakkan kedaulatan rakyatsebagaiasaspendiriannegara RepublikIndonesiatelahdisepakati dan dituangkan dalam alinea IV Pembukaan UUD NRI 1945, yang berbunyi: “...maka disusunlah kemerdekaan kebangsaan Indonesia itu dalam suatu Undang-Undang Dasar Republik Indonesia, yang terbentuk dalam suatu susunan negara Indonesia yang berkedaulatan rakyat...”. ${ }^{1}$ C.S.T Kansil mengartikan "kedaulatan rakyat" yang tercantum dalam Pembukaan Undang-Undang Dasar (UUD NRI) Tahun 1945 ini dengan istilah "demokrasi". ${ }^{2}$ Negara yang menganut sistem demokrasi semestinya diselenggarakan berdasarkan kehendak dan kemauan rakyat mayoritas namun juga tidak mengesampingkan minoritas. ${ }^{3}$ Kebutuhan terhadap mekanisme pelaksanaan kedaulatan rakyat ini merupakan suatu hal yang niscaya bagi negara Indonesia, khususnya dalam hal pengisian jabatan Presiden dan Wakil Presiden Republik Indonesia.

Persoalan yang kemudian timbul, Pasal 6A ayat (2) UUD NRI Tahun 1945 menentukan bahwa "Pasangan calon Presiden dan Wakil Presiden diusulkan oleh partai politik atau gabungan partai politik peserta pemilihan umum sebelum pelaksanaan pemilihan umum". Ketentuan yang mengatur bahwa pasangan calon Presiden dan Wakil Presiden harus terlebih dahulu diusulkan hanya oleh

1 Ni'matul Huda \& Imam Nasef, Penataan Demokrasi dan Pemilu (Jakarta: Kencana, 2017), hlm. 161.

2 C.S.T Kansil, Memahami Pemilihan Umum dan Referendum: Sarana Demokrasi Pancasila (Jakarta: Ind-Hill-Co, 1986), hlm. 1.

3 Dalam demokrasi, kekuasaan mayoritas harus memperhatikan hak-hak minoritas, agar tidak menjadi dikatator mayoritas atas minoritas. Namun sebaliknya pula, bukan pula demokrasi jika pemerintahan bertentangan dengan kehendak mayoritas. Karena itu kehendak masyarakat dalam demokrasi terbentuk melalui diskusi yang berkelanjutan antara mayoritas dan minoritas yang menghasilkan kompromi sebagai bagian yang alami dari demokrasi. Muchammad Ali Safa'at, "Klasifikasi Negara Demokrasi Menurut Arend Lijphart”, http://safaat.lecture.ub.ac.id/files/2012/04/ Klasifikasi-Negara-Demokrasi-Menurut-Arend-Lijphart.pdf, 21/4/2012, diakses $15 / 6 / 2020$. 
parpol atau gabungan parpol peserta pemilihan umum (pemilu) ini dinilai tidak konsisten dengan asas kedaulatan rakyat sebagaimana tertuang dalam Pembukaan UUD dan ditegaskan lebih lanjut dalam Pasal 1 ayat (2) UUD. ${ }^{4}$ Prosedur tersebut secara otomatis menutup rekrutmen pasangan calon Presiden dan Wakil Presiden melalui jalur perseorangan. Sehebat apapun personal seseorang yang hendak maju sebagai calon presiden, dipastikan tidak akan lolos sebagai calon apabila tidak "menunggangi kendaraan" yang berupa parpol.

Ketentuan tentang pasangan calon Presiden dan Wakil Presiden yang hanya dapat diusulkan oleh parpol atau gabungan parpol ini sebenarnya telah beberapa kali diajukan pengujiannya ke Mahkamah Konstitusi (MK). ${ }^{5}$ Uji materi diajukan oleh sejumlah pemohon agar mekanisme pencalonan Presiden dan Wakil Presiden dapat dilakukan tidak hanya melalui jalur parpol atau gabungan parpol. Mereka di antaranya adalah, Agus Abdul Jalil (Ketua Yayasan Pengembangan Reformasi Nasional, YPRN), ${ }^{6}$ Yislam Alwini beserta tujuh rekannya yang berlatar belakang wiraswasta, ${ }^{7}$ dan Mulyo Wibisono bersama Dion Bambang Soebroto, yang mengaku sebagai calon Presiden dan Wakil Presiden. ${ }^{8}$ Mereka mengajukan uji materi Undang-Undang Nomor 23 Tahun 2003 tentang Pemilihan Umum Presiden dan Wakil Presiden. Namun, dikarenakan dari ketiga permohonan tersebut tidak ada yang dikabulkan, maka pada 2008 menjelang Pemilu 2009 di bawah rezim Undang-Undang Nomor 42 Tahun 2008 tentang Pemilihan Umum Presiden dan Wakil Presiden, ketentuan serupa

4 Huda dan Nasef, Penataan Demokrasi dan, hlm. 162-163.

5 Permohonan judicial review terhadap UU Nomor 42 Tahun 2008 tentang Pemilihan Presiden dan Wakil Presiden telah diajukan sebanyak dua kali secara terpisah. Untuk yang pertama diajukan oleh M. Fadjroel Rachman, Mariana. Bob Febrian, Taufik Basari, S.H., S.Hum, LL.M, dkk. selaku Kuasa Pemohon. Semantara untuk pengajuan kedua pemohonnya lebih didominasi oleh parpol diantaranya, Saurip Kadi, Partai Bulan Bintang, DPP Hanura, PKN Partai Demokrasi Pembaruan, DPP Partai Indonesia Sejahtera, DPP Partai Buruh, DPP Partai Peduli Rakyat Nasional \& DPP Partai Republika Nusantara.

6 Putusan MK Nomor 007 / PUU-II/ 2004.

7 Putusan MK Nomor 054/PUU-II/ 2004.

8 Putusan MK Nomor 057/PUU-II/ 2004. 
kembali diuji materi ke MK oleh Saurip Kadi, ${ }^{9}$ M. Fadjroel Rachman, beserta kedua rekan pemohon yang lainnya. ${ }^{10}$ Permohonan ini pun kembali ditolak oleh MK. ${ }^{11}$

Fakta bahwa jalur rekrutmen pasangan calon Presiden dan Wakil Presiden hanya tersedia melalui parpol ini merupakan persoalan hukum ketatanegaraan yang membutuhkan solusi. Meski MK telah berkali-kali menolak permohonan perluasan jalur pencalonan Presiden, belum tentu juga gagasan yang berkembang mengenai perluasan jalur pencalonan Presiden ini tidak sejalan dengan prinsip bernegara Indonesia. Oleh karena bila dibiarkan, parpol justru akan terus memonopoli sistem rekrutmen jabatan Presiden, sehingga hal ini dapat mereduksi prinsip negara hukum dan demokrasi. Berbagai pendapat tentang persoalan ini menyimpulkan memang harus dibuka jalur rekrutmen pasangan calon Presiden dan Wakil Presiden di luar melalui jalur parpol. ${ }^{12}$

Namun, pengimplementasian kedaulatan rakyat berdasarkan prinsip negara hukum dan demokrasi Indonesia memang tidak boleh dilakukan secara arogan. Desain hukumnya harus diatur secara proporsional dengan memadukan prinsip negara demokrasi dan negara hukum, yang meski pada hakikatnya kedua konsep tersebut berangkat dari konstruksi yang saling bertolak belakang. ${ }^{13}$ Di satu sisi

9 Putusan MK Nomor 51-52-59/PUU-VI/ 2008.

10 Putusan MK Nomor 56/PUU-VI/2008.

11 Putusan MK Nomor 56/PUU-VI/ 2008.

12 Misalnya, Huda dan Nasef, Penataan Demokrasi dan Pemilu; Mitra Aisha, Mexsasai Indra, dan Junaidi, "Gagasan Calon Perseorangan dalam Pemilihan Presiden dan Wakil Presiden dalam Sistem Ketatanegaraan Indonesia”, http: / / jom.unri.ac.id/index.php/JOMFHUKUM/article/view/5524; dan Siti Rodhiyah Dwi Istinah, "Gagasan Calon Presiden dan Wakil Presiden Perseorangan dalam Rangka Peningkatan Kualitas Demokrasi Indonesia”, Jurnal Hukum Fakultas Hukum Unissula, 28, 2 (2012). Secara umum sejumlah literatur dan penelitian tentang persoalan ini menyimpulkan bahwa memang harus dibuka jalur rekrutmen pasangan calon Presiden dan Wakil Presiden di luar jalur parpol. Namun, berbagai kajian tersebut belum ada yang mengkaji hingga menyentuh pada relevansinya dengan prinsip negara hukum dan demokrasi Indonesia.

13 Lihat Pasal 1 ayat (2) dan Pasal 1 ayat (3) Undang-Undang Dasar Negara Republik Indonesia Tahun 1945. 
negara demokrasi adalah negara yang diselenggarakan berdasarkan kehendak rakyat. ${ }^{14}$ Sedangkan negara hukum ialah konsep yang menghendaki pengurusan negara harus dan tetap berdasar pada koridor hukum sebagai pengarah maupun pembatasnya. Perpaduan antara konsep negara demokrasi dan negara hukum inilah yang kemudian disebut dengan demokrasi konstitusional. ${ }^{15}$

Meski gagasan pencalonan Presiden dan Wakil Presiden melalui jalur non parpol jamak mengemuka, ia perlu dikaji relevansinya dengan prinsip negara hukum dan demokrasi, agar diperoleh landasan teoretis dan argumentatif yang berkesesuaian dengan ajaran demokrasi konstitusional Indonesia. Sejumlah penelitian sebelumnya tidak sampai pada analisis yang mengaitkan gagasan ini dengan prinsip negara hukum dan demokrasi Indonesia. Karenanya, artikel ini mencoba mengurai dan memperkaya kajian mengenai gagasan pencalonan Presiden dan Wakil Presiden melalui jalur perseorangan berdasarkan prinsip negara hukum dan demokrasi.

Dalam artikel ini, pembahasan gagasan pencalonan Presiden dari jalur perseorangan dimulai dengan terlebih dahulu mengulas konsep negara hukum dan demokrasi beserta prinsip-prinsip yang terkandung di dalamnya. Uraian ini penting, karena pada bagian berikutnya akan dijadikan sebagai tolok ukur dalam mendiksuikan apakah gagasan pencalonan Presiden melalui jalur perseorangan relevan. Artikel ini diakhiri dengan penyampaian kesimpulan: bagaimana relevansi gagasasan pencalonan presiden jalur perseroangan terhadap prinsip negara hukum dan demokrasi.

\section{B. Negara Hukum dan Demokrasi}

Kajian mengenai prinsip negara hukum dan demokrasi telah banyak dilakukan oleh sejumlah ahli. Secara sekilas, antara konsep negara hukum dan demokrasi ini memang terlihat bertolakbelakang,

14 Amiramachmud, "Demokrasi, Undang-Undang dan Peran Rakyat", dalam Mahfud MD, Hukum dan Pilar-Pilar Demokrasi (Yogyakarta: Gama Media,1999), hlm. 8.

15 Jimly Asshiddiqie, Konstitusi dan Konstitusionalisme Indonesia (Jakarta: Sinar Grafika, cetakan ketiga, 2014), hlm. 58. 
dikarenakan karakternya yang tampak berbeda. Namun, keduanya justru sering disebut lahir dari ibu kandung yang sama. ${ }^{16}$ Jika melihat sejarahnya, gagasan negara hukum dilatarbelakangi atas kekuasaan raja yang absolut dan sewenang-wenang (absolutisme) pada masa lampau, begitupun lahir dan muncul kembalinya konsep demokrasi sebagai bentuk protes terhadap kekuasaan feodal. ${ }^{17}$ Kedua variabel tersebut (negara hukum dan demokrasi) pada intinya meletakkan fondasi bagi berdirinya suatu negara yang diorientasikan untuk menyejahterakan rakyatnya. Sebab, dengan tidak ada kekuasaan yang sewenang-wenang dan kebebasan rakyat dijamin, maka diyakini dapat mendorong terwujudnya kesejahteraan.

Perkembangannya, kedua prinsip tersebut diterapkan secara kolaboratif dengan sebutan "negara hukum yang demokratis". Prinsip negara hukum yang demokratis ini merupakan komposisi yang cukup ideal, lantaran keduanya bersifat saling melengkapi. Suatu negara yang hanya berlandaskan pada hukum maka ia akan kaku dan pasif (statis); begitupun negara yang hanya berlandaskan pada demokrasi semata maka akan menjadi kacau dan tidak terkendalikan. Sebagai ilustrasi sekaligus rujukan, berikut pernyataan Ignacio Sanches-Cuenca yang mengakui ada relasi antara negara hukum dan demokrasi setelah mengkaji konsep rule of law (konsep negara hukum anglo saxon).

"If we accept that this system is a rule of law, we are bound to accept that a dictator with a legal system could be a rule of law. For some, this is almost a heresy. For others, there is nothing wrong or absurd about this

16 Dalam berbagai literatur dijelaskan gagasan demokrasi muncul kembali setelah tenggelam karena takluknya Romawi terhadap Eropa Barat, yang kemudian diikuti oleh prinsip negara hukum sebagai prosedur untuk memproses aspirasi rakyat dan prosedur untuk menegakkannya. Begitupun di Perancis yang merupakan tonggak berdirinya negara demokrasi (yang ditandai dengan lahirnya pencabangan kekuasaan negara yang kemudian dikenal sebagai Trias Politica) sekaligus disusul pula dengan lahirnya negara hukum. Untuk itu ada yang mengatakan bahwa tidak akan ada demokrasi tanpa ada hukum yang tegak dan tidak akan ada hukum yang tegak tanpa pembangunan politik yang demokratis. Lebih lanjut baca Mahfud MD, Hukum dan Pilar-Pilar, hlm. 176.

17 Ni'matul Huda, Negara Hukum, Demokrasi, dan Judicial Review (Yogyakarta: UII Press, 2005), hlm. 1-15. 
conclusion: some doctrines of the rule of law (notably in Germany) were born without any democratic pedigree." 18

Secara lebih tegas Michel Tropper juga mengemukakan relasi antara negara hukum dan demokrasi, "The strength of the theory of the rechtstaat comes from its relation with democratic theory". ${ }^{19}$ Ini artinya, kekuatan teori negara hukum (rechtstaat) tidak terletak dalam dirinya sendiri, melainkan dalam hubungannya dengan teori demokrasi. Karena itu, keduanya harus berkolaborasi untuk menjadi prinsip bernegara yang saling melengkapi. ${ }^{20}$ Gagasan demokrasi menuntut agar setiap bentuk undang-undang dan berbagai keputusan mendapatkan persetujuan dari rakyat dan sebanyak mungkin memperhatikan kepentingan rakyat, sementara gagasan negara hukum menuntut agar penyelenggaraan kenegaraan dan pemerintahan harus didasarkan pada undang-undang dan memberikan jaminan terhadap hak-hak dasar rakyat. ${ }^{21}$

Sebagai suatu prinsip sekaligus sistem bernegara, konsep negara hukum dan demokrasi ini dapat berfungsi sebagai "neraca bernegara”. Misalkan, seiring berjalannya waktu muncul gagasan baru mengenai sistem atau mekanisme pemerintahan, maka sebagai negara hukum yang demokratis perlu mengakomodasi untuk kemudian dipertimbangkan. Begitu pula, apabila gagasan baru tersebut dinilai keluar atau menyimpang dari pilar-pilar bernegara, maka sebagai negara demokrasi yang berdasarkan hukum perlu juga untuk mengendalikannya. Dengan begitu, suatu bangsa tidak akan terjebak pada anggapan bahwa sistem pemerintahan adalah hal "tabu” lantaran sikap yang cenderung konservatif. ${ }^{22}$

18 Demikian menurut Ignacio Sanches-Cuenca, sebagaimana dikutip Jimly Asshiddiqie, Pokok-pokok Hukum Tata Negara Indonesia Pasca Reformasi (Jakarta: PT. Bhuana Ilmu Populer, 2007), hlm. 300.

19 Asshiddiqie, Pokok-pokok Hukum, hlm. 300.

20 Asshiddiqie, Pokok-pokok Hukum, hlm. 302.

21 Ridwan HR, Hukum Administrasi Negara (Jakarta: Rajawali Pers, 2020), hlm. 94

22 Sejarah Indonesia menunjukkan pernah mengalami hal demikian, sebagaimana pada masa orde baru yang meletakkan UUD 1945 sebagai sesuatu yang 'tabu', sehingga pada saat itu sangat mustahil untuk melakukan perubahan Konstitusi. 
Dalam artikel ini dibahas kesesuaian antara gagasan mengakomodasi pencalonan Presiden dan Wakil Presiden dari jalur perseorangan dengan prinsip negara hukum dan demokrasi Indonesia. Meski tidak tergolong baru, gagasan ini dipandang penting untuk selalu diperbarui agar dapat diimplementasikan dalam kehidupan bernegara hukum yang demokratis sebagaimana di Indonesia. Tujuan dilakukannya analisis ini adalah untuk menguji kesesuaian gagasan dengan prinsip negara hukum dan demokrasi. Gagasan ini sejauh ini tampaknya belum dikaji dari perspektif prinsip negara hukum dan demokrasi Indonesia. Pilihan untuk mengkaji dengan perspektif tersebut penting karena keduanya telah menjadi prinsip yang dianut dalam bernegara Indonesia.

Gagasan negara hukum ditujukan agar pemerintahan negara tidak asal dijalankan berdasar kehendak hati orang yang sedang mendapat amanah untuk memerintah. Setiap tindakan yang dilakukan oleh pemerintah harus terlebih dahulu diatur dalam peraturan (hukum). Hukum dalam konteks ini bersifat membatasi tindakan pemerintah agar tidak keluar dari jalur yang telah ditentukan. Hukum adalah primer, sehingga apa yang diatur dalam hukum itu adalah tujuan yang harus diwujudkan oleh pemerintah. Namun dalam perkembangannya tidak sesederhana itu, konsep negara hukum mulai menyesuaikan diri terhadap kebutuhan masyarakat yang semakin kompleks. Karena itu, pemahamannya mulai bergeser bahwa hukum bukan lagi sebagai tujuan, melainkan sebagai sarana (instrument) yang berfungsi sebagai pemandu (guidance) untuk mencapai tujuan suatu negara. Apabila hukum (termasuk konstitusi) tidak mampu lagi menuntun tercapainya tujuan bernegara, maka perubahan terhadapnya merupakan suatu keniscayaan.

Demokrasi (kerakyatan) dipahami sebagai suatu sistem pemerintahan yang meletakkan rakyat sebagai subjek primer. Sisi kemanusiaan yang melekat pada tiap-tiap rakyat mendorong terciptanya suatu sistem bernegara yang berkedaulatan rakyat. Karena itu, dalam setiap bidang penyelenggaraan pemerintahan negara harus 
meletakkan rakyat sebagai pihak yang selalu menentukan. ${ }^{23}$ Gagasan demokrasi ini menghendaki adanya mekanisme penyelenggaraan pemerintahan negara yang aksesibel untuk mengakomodasi partisipasi seluruh rakyat baik secara langsung atau tidak langsung. Karena itu, kajian tentang demokrasi menawarkan berbagai bentuk prosedur penyelenggaraan pemerintahan yang demokratis, seperti adanya jaminan terhadap hak asasi manusia, pemilihan umum, serta berbagai aksesibilitas untuk menjamin keikutsertaan rakyat dalam pemerintahan.

Prinsipnya, jangan sampai suatu negara hanya diperintah (diurus) oleh satu atau segelintir orang saja. Sistem demokrasi menjamin agar setiap rakyat dapat ikut serta mengurus negara secara langsung, namun apabila dengan terpaksa rakyat tidak dapat ikut serta secara langsung (tidak langsung) maka harus dijamin akses partisipasi yang sebesar-besarnya. ${ }^{24}$ Karena itu, Afan Gaffar menentukan salah satu elemen empirik sebagai konsekuensinegara demokrasi, adalah adanya rekrutmen politik yang bersifat terbuka untuk mengisi posisi-posisi politik yang penting di dalam proses penyelenggaraan negara. ${ }^{25}$

Hukum dan peraturan perundang-undangan (termasuk Konstitusi) yang berlaku di suatu negara tidak boleh ditetapkan dan diterapkan secara sepihak oleh dan/atau hanya untuk kepentingan penguasa secara bertentangan dengan prinsip-prinsip demokrasi. ${ }^{26}$ Oleh karenanya, penggabungan konsep negara hukum dan demokrasi ini dianut di Indonesia sebagai suatu prinsip bernegara. Hal itu tertuang dalam Konstitusi, Pasal 1 ayat (2) dan Pasal 1 ayat (3) UUD

23 Mohammad Hatta, Demokrasi Kita, dan Pikiran-pikiran tentang Demokrasi \& Kedaulatan Rakyat (Bandung: SEGA ARSY, cetakan kedua, 2009), hlm. 2425.

24 Secara harfiah, demokrasi berarti "pemerintahan rakyat" artinya bahwa rakyat yang menentukan segalanya, bisa juga diartikan rakyat hanya menikmati kemanfaatannya tanpa harus ikut campur dalam penyelenggaraannya. Lihat Mahfud MD, Hukum dan Pilar-Pilar Demokrasi, hlm. 180.

25 Afan Gaffar, Politik Indonesia Transisi Menuju Demokrasi (Yogyakarta: Pustaka Pelajar, 2001), hlm. 15.

26 Asshiddiqie, Konstitusi dan Konstitusionalisme Indonesia, hlm. 132. 
NRI Tahun $1945 .^{27}$

\section{Pencalonan Presiden dan Wakil Presiden Jalur Perseorangan dan Prinsip Negara Hukum dan Demokrasi}

Bagian ini hendak membangun argumentasi pencalonan Presiden dan Wakil Presiden melalui jalur perseorangan dikaitkan dengan prinsip negara hukum dan demokrasi. Setidaknya ada empat bangunan argumentasi yang relevan: jaminan hak konstitusional warga negara, aktualisasi diri warga negara dalam kehidupan politik secara mandiri, rekrutmen politik yang bersifat terbuka, dan kekuasaan pemerintahan di tangan rakyat. Keempat hal tersebut merupakan elaborasi ajaran prinsip negara hukum dan demokrasi, sebagaimana dikemukaan oleh, antara lain, Miriam Budiardjo, Affan Gaffar, Jimly Asshiddiqie, dan Ni'matul Huda.

\section{Jaminan Hak Konstitusional Warga Negara}

Gagasan negara hukum rechtstaat dari Freidrich Julius Stahl yang diilhami oleh Immanuel Kant menegaskan bahwa konsep negara hukum rechtstaat mengandung unsur-unsur, antara lain: (a) perlindungan hak-hak asasi manusia; (b) pemisahan atau pembagian kekuasaan untuk menjamin hak-hakitu;(c) pemerintahan berdasarkan peraturan perundang-undangan; dan (d) peradilan administrasi dalam perselisihan. ${ }^{28}$

Menurut Mac Iver, negara adalah anak dan orang tua sekaligus dari hukum (the state is both the child and the parents of law) ${ }^{29}$ Rechtstaat memberikan persyaratan dasar bagi suatu negara hukum sebagai berikut:

a. Asas legalitas, bahwa setiap tindakan pemerintah harus didasarkan atas dasar peraturan perundang-undangan (wettelijk grondslag);

27 Gaffar, Politik Indonesia Transisi, hlm. 15.

28 Miriam Budiardjo, Dasar-dasar Ilmu Politik (Jakarta: Gramedia, 1982), hlm. 57-58; Philipus M. Hadjon, Perlindungan Hukum Bagi Rakyat di Indonesia (Surabaya: Bina Ilmu, 1987), hlm. 72.

29 Wirjono Prodjodikoro, Asas-Asas Ilmu Negara dan Politik (Jakarta: PT. Eresco, 1981), hlm. 38. 
b. Pembagian kekuasaan, yang berarti kekuasaan negara tidak boleh bertumpu hanya pada satu tangan kekuasaan;

c. Hak-hak dasar merupakan sasaran perlindungan hukum bagi rakyat dan sekaligus membatasi kekuasaan pembentukan undangundang; dan

d. Pengawasan pengadilan, sehingga tersedia saluran bagi rakyat untuk menguji keabsahan tindakan pemerintahan (rechtmatigheids toesting). ${ }^{30}$

Selanjutnya muncul pula konsep negara hukum (rule of law) dari A.V. Dicey, lahir dalam naungan sistem hukum anglo-saxon yang unsur-unsurnya sebagai berikut:

a. Supremasi aturan-aturan hukum (supremacy of the law), yaitu tidak ada kekuasaan sewenang-wenang (absence of arbitrary power), dalam arti bahwa seseorang hanya boleh dihukum kalau melanggar hukum;

b. Kedudukan yang sama dalam menghadapi hukum (equality before the law);

c. Terjaminnya hak-hak manusia oleh undang-undang (di negara lain oleh undang-undang dasar) serta keputusan-keputusan pengadilan. ${ }^{31}$

Apabila mencermati berbagai konsep negara hukum tersebut, hak asasi manusia merupakan prinsip fundamental sekaligus unsur yang selalu ada dalam konsep negara hukum apapun (rechtstaat maupun the rule of law). Sebagai prinsip yang fundamental, hak asasi manusia menduduki posisi penting dalam penyelenggaraan negara. Posisi penting dimaksud adalah, baik dalam dimensi normatif maupun dimensi pelindungannya harus dijamin oleh negara. Karena itu tidak heran apabila secara normatif negara Indonesia meletakkan jaminan hak asasi manusia dalam konstitusi (UUD NRI Tahun 1945), yang dalam bahasa hukum tata negara disebut sebagai hak konstitusional warga negara. ${ }^{32}$

30 Muntoha, Negara Hukum Indonesia Pasca Perubahan UUD 1945 (Bantul: Kaukaba, 2013), hlm. 9.

31 Budiardjo, Dasar-dasar Ilmu, hlm. 58.

32 Lihat BAB XA UUD NRI 1945. 
Pengakuan, perlindungan, penghormatan, dan pemenuhan terhadap hak asasi manusia (HAM) merupakan salah satu elemen (unsur) penting dalam negara hukum yang demokratis. ${ }^{33}$ Sebagaimana karakteristik negara hukum rechtstaat dan rule of law, yang apabila disandingkan sama-sama memuat prinsip HAM, begitu pula dalam prinsip demokrasi, yang secara hakiki disebut oleh John Dewey bukan merupakan tujuan, melainkan alat untuk menemukan dan memperluas sifat dasar dan HAM yang fundamental, guna menghasilkan manusia sejati. ${ }^{34}$ HAM yang dimaksud dalam konteks ini adalah hak sipil-politik.

Perlu diketahui bahwa terdapat tiga klasifikasi HAM berdasarkan generasinya. Sebagaimana dikatakan Karel Vasak, ${ }^{35}$ ahli hukum Perancis, generasi HAM pertama mengedepankan kebebasan masyarakat dari suatu bentuk pengekangan yang dilakukan oleh negara, dan lebih bertendensi pada penghargaan atas ketiadaan intervensi negara dalam pencarian martabat manusia. ${ }^{36}$ Pada hakikatnya hak ini bertujuan untuk melindungi kepentingan kehidupan pribadi manusia, serta menghormati setiap orang atas dirinya sendiri (kedaulatan individu). Hak ini menjamin suatu kebebasan di mana setiap individu sendirilah yang berhak menentukan dirinya sendiri. Generasi kedua berasal dari tradisi sosialis yang terdapat di antara kaum Saint-Simon di Perancis pada awal abad 19 kemudian dicanangkan dengan berbacai cara oleh perjuangan revolusioner dan

33 Asshiddiqie, Pokok-pokok Hukum, hlm. 306.

34 John Dewey adalah seorang filsuf dan pendidik Amerika, gagasannya tentang demokrasi dikutip oleh Noam Chomsky. Meski demikian, Dewey mengakui bahwa demokrasi dalam pengertian tersebut bagaikan "tanaman layu”, karena dominasi kekuatan "institusi bank dan perseoran kaya”, sehingga masyarakat hanya dibawah bayang-bayang bisnis besar. Lihat Noam Chomsky, How The World Works, terj. Tia Setiadi (Yogyakarta: PT Bentang Pustaka, cetakan ketiga, 2017), hlm. 193.

35 Rhona K.M. Smith, dkk., Hukum Hak Asasi Manusia, ed. Knut D. Asplund, Suparman Marzuki, dan Eko Riyadi (Yogyakarta: PUSHAM UII, 2008), hlm. 14-17.

36 Eko Riyadi, "Politik Hukum Hak Asasi Manusia: Kajian terhadap UndangUndang Nomor 7 Tahun 2004 tentang Air”, dalam Mengurai Kompleksitas Hak Asasi Manusia, ed. Eko Riyadi dan Supriyanto Abdi (Yogyakarta: PUSHAM UII, 2007), hlm. 247. 
kesejahteraan. Dalam generasi kedua ini, penekanan pada intervensi negara sangat terbuka lebar. Hal ini dipandang sebagai tindakan strategis karena dengan kontribusi negara partisipasi yang merata dalam produksi dan distribusi dimungkinkan terpenuhi. HAM generasi kedua lebih menekankan dalam konteks tuntutan untuk persamaan sosial (claims to sosial equality). Pada generasi ketiga, muncul tuntutan dari negara-negara berkembang atas tatanan internasional yang adil menimbulkan adanya keinginan terjaminnya hak solidaritas atau hak bersama. Adapun hak solidaritas atau hak bersama yang diinginkan oleh negara-negara berkembang antara lain ialah: (i) hak atas pembangunan (the right to development); (ii) hak atas perdamaian, (iii) hak atas sumber daya alam sendiri; (iv) hak atas lingkungan hidup yang baik; (v) hak atas warisan budaya sendiri.

Berkaca pada tiga generasi HAM tersebut, maka generasi HAM yang pertama merupakan klasifikasi HAM yang sesuai dengan penelitian ini. Hal itu dikarenakan, mekanisme pencalonan pasangan calon Presiden dan Wakil Presiden tergolong dalam hak sipil dan politik. ${ }^{37}$ Sementara itu, HAM generasi pertama ini juga sering disebut dengan hak negatif (negative right). Disebut sebagai hak negatif karena negara harus abstain, diam atau tidak melakukan campur tangan untuk merealisasikan hak-hak tersebut. ${ }^{38}$ Karena itu, hak untuk mencalonkan diri sebagai calon Presiden dan Wakil Presiden itu idealnya tidak diintervensi oleh negara.

Intervensijustruterlihatdenganadanyaregulasiyangmenentukan prosedur pencalonan hanya dapat (harus) diusulkan oleh parpol atau gabungan parpol (Pasal 6A ayat (2) UUD NRI Tahun 1945). Jika yang diatur adalah persyaratan mengenai kualifikasi kecakapan personal

37 Hak sipil merupakan kebebasan individu dari campur tangan pihak lain, khususnya negara. Contoh: kebebasan berpikir, berkeyakinan dan beragama, kebebasan berpendapat, dan kebebasan bergerak. Sedangkan hak politik merupakan kebebasan individu untuk turut campur atau turut serta menentukan kebijakan politik negara. Contoh: hak untuk berdemonstrasi, hak atas kebebasan untuk memilih dan dipilih (legislatif/eksekutif), hak untuk mendirikan/bergabung pada partai politik. Lebih lanjut baca Eko Riyadi, Hukum Hak Asasi Manusia: Perspektif Internasional, Regional dan Nasional (Depok: Rajawali Pers, 2018), hlm. 50.

38 Riyadi, Hukum Hak Asasi Manusia, hlm. 47-48. 
tertentu, ${ }^{39}$ tentu masih dapat dikatakan dalam batas wajar mengingat jabatan Presiden dan Wakil Presiden membutuhkan sosok yang berkualitas. Namun lain halnya apabila negara mengatur mekanisme pencalonan hanya dapat dilakukan dengan diusulkan oleh parpol atau gabungan parpol. Padahal MK dalam sejumlah putusannya juga telah mendorong pelonggaran sejumlah persyaratan pelaksanaan hak untuk dipilih yang berangkat dari semangat bahwa pembatasan hak dipilih dalam pemilu hanya dapat didasarkan atas pertimbangan ketidakcakapan. ${ }^{40}$

Pemaksaan terhadap warga negara yang tidak menaruh minat menyalurkan hak politiknya melalui parpol, agar kemudian harus menyalurkannya melaluiparpoljustrumerupakanbentukintervensi. ${ }^{41}$

39 Syarat-syarat personalitas bakal calon ini misalnya yang diatur dalam Pasal 6 UUD NRI 1945. Terdapat perbedaan antara persyaratan personal sebagaimana dalam Pasal 6 UUD NRI 1945 dengan prosedur pencalonan yang harus melalui parpol atau gabungan parpol sebagaimana Pasal 6A ayat (2) UUD NRI 1945. Persyaratan personal lebih bergantung pada faktor internal yaitu kondisi personal bakal calon, sedangkan prosedur pengusulan itu tidak bergantung pada personal bakal calon, melainkan lebih kepada faktor eksternal yaitu sejauh mana kedekatannya dengan parpol, lobi politiknya dengan parpol, bahkan deal-deal politiknya dengan parpol yang hendak mengusung.

40 Putusan MK Nomor 011-017/PUU-I/ 2003 terkait syarat calon bukan bekas anggota organisasi terlarang Partai Komunis Indonesia, termasuk organisasi massanya, atau bukan orang yang terlibat langsung ataupun tidak langsung dalam G30S / PKI, atau organisasi terlarang lainnya dinyatakan bertentangan dengan UUD NRI 1945; Putusan Nomor 5/PUU-V/2007 yang membuka peluang bagi calon perseorangan (tidak diusung parpol) untuk berkompetisi dalam Pilkada; Putusan Nomor 14-17/ PUU-V/2007 terkait dengan syarat tidak pernah dijatuhi pidana penjara berdasarkan putusan pengadilan yang telah mempunyai kekuatan hukum tetap karena melakukan tindak pidana yang diancam pidana penjara lima tahun atau lebih juga sempat ditiadakan untuk jabatan publik yang dipilih, meski pada Putusan Nomor 4/PUUVII/ 2009 dan Putusan Nomor 42/PUU-XIII/ 2015MK menafsirkan dengan inkonstitusional bersyarat. Lihat Pan Mohamad Faiz, "Memperkuat Prinsip Pemilu Teratur, Bebas, dan Adil Melalui Pengujian Konstitusionalitas Undang-Undang, Jurnal Konstitusi, 14, 3 (2017), hlm. 673-700. Lihat juga Khairul Fahmi, "Pergeseran pembatasan Hak Pilih dalam Regulasi Pemilu dan Pilkada”, Jurnal Konstitusi, 14, 4 (2017), hlm. 758-777

41 Pemaksaan ini dapat berkonsekuensi terhadap 2 (dua) objek, pertama,warga negara yang hendak mencalonkan diri terpaksa harus berafiliasi dengan parpol, kedua,warga negara yang hendak menggunakan hak pilihnya 
Seharusnya negara menghormati (respect) cara warga negara dalam menyalurkan hak politiknya. Namun dalam hal ini, secara tidak langsung negara (melalui konstitusi) telah bertindak aktif dengan cara mengatur pencalonan Presiden dan Wakil Presiden hanya melalui jalur parpol atau gabungan parpol. Ketentuan tersebut tentu berkonsekuesi pada keharusan warga negara untuk berpartai politik atau setidak-tidaknya berafiliasi dengan partai politik. Sehingga, hak dan kebebasan warga negara untuk menyalurkan hak politiknya tidak lagi leluasa.

Bentuk intervensi hak politik ini awalnya memang sebatas ketika negara memaksa warga negara untuk memilih atau mengikuti partai politik tertentu. ${ }^{42}$ Namun dalam perkembangannya, terdapat bentuk lain intervensi hak politik ini, yaitu "memaksa" seseorang untuk menyalurkan aspirasi politiknya hanya melalui partai politik, sedangkan bagi warga negara yang hendak menjadi calon Presiden dan Wakil Presiden harus mengikuti partai politik atau setidaktidaknya berafiliasi dengan partai politik. Padahal sarana (infrastruktur politik) untuk menyalurkan hak politik di dalam negara hukum yang demokratis itu tidak sebatas hanya melalui parpol, melainkan terdapat berbagai ragam infrastruktur politik lain yang sama-sama merupakan sarana yang berfungsi untuk menyalurkan hak politik. ${ }^{43}$

Secara normatif, peraturan perundang-undangan di Indonesia

terpaksa harus memilih pasangan calon yang memiliki afiliasi dengan parpol atau gabungan parpol.

42 Eko Riyadi mencontohkan pelanggaran HAM by commission terjadi apabila setiap orang yang memiliki hak untuk bebas memilih partai politik sesuai dengan pilihan bebasnya, namun ketika negara aktif melakukan pemaksaan agar masyarakat memilih partai politik tertentu, maka negara dianggap melakukan pelanggaran by commission. Lebih lanjut baca Riyadi, Hukum Hak Asasi Manusia, hlm. 72.

43 Seiring dengan jaminan dan perlindungan terhadap HAM, terutama hak atas kemerdekaan berserikat, berkumpul, menyatakan pikiran secara lisan maupun tulisan berkonsekuensi pada berkembangnya kelompok-kelompok masyarakat yang biasanya disebut kelompok kepentingan (interest gorups). Gabriel A. Almond dan Bingham G. Powell membagi kelompok-kelompok masyarakat dalam empat kategori: kelompok anomi; kelompok nonasosiasional; kelompok institusional; dan kelompok asosiasional. Budiardjo, Dasar-dasar Ilmu Politik, hlm. 387-92. 
memang tidak ada yang mengatur larangan "memaksa" seseorang untuk memasuki suatu organisasi tertentu (partai politik). Namun, ketentuan mengenai larangan memaksa seseorang harus masuk organisasi tertentu dapat ditemukan dalam Pasal 20 ayat (2) Deklarasi Universal Hak Asasi Manusia (DUHAM), bahwa "tidak seorang pun dapat dipaksa memasuki salah satu perkumpulan”. Kovenan Internasional tentang Hak-hak Sipil dan Politik (International Covenant on Civil and Political Rights, ICCPR) juga telah menentukan jaminan hak dan kesempatan bagi setiap warga negara untuk berpolitik secara bebas. Pasal 25 ICCPR mengatur, setiap warga negara harus mempunyai hak dan kesempatan, tanpa pembedaan apapun untuk a) ikut serta dalam pelaksanaan urusan pemerintahan, baik secara langsung ataupun melalui wakil-wakil yang dipilih secara bebas; dan b) memilih dan dipilih pada pemilihan umum berkala yang murni, dan dengan hak pilih yang universal dan sama, serta dilakukan melalui pemungutan suara secara rahasia untuk menjamin kebebasan menyatakan keinginan dari para pemilih.

Apabila Pasal 20 ayat (2) DUHAM tersebut disandingkan dengan Pasal 6A ayat (2) UUD NRI Tahun 1945, secara tidak langsung tentu terjadi kontradiksi. Meskipun frasa "diusulkan oleh partai politik atau gabungan partai politik" memang tidak mengharuskan seorang warga negara masuk menjadi anggota parpol, dalam praktiknya pasangan calon Presiden atau Wakil Presiden terpaksa menjadi "petugas partai” yang tentunya memiliki pertalian atau afiliasi dengan parpol pengusungnya ${ }^{44}$ Oleh karena itu, Pasal 6A ayat (2) UUD NRI Tahun 1945 ini cenderung "memaksa" warga negara Indonesia untuk masuk dalam partai politik atau setidak-tidaknya berafiliasi dengan partai politik. Bahkan bagi warga negara yang memiliki hak pilih, terpaksa menyalurkan aspirasi politiknya melalui calon dari kalangan partai politik. Padahal UUD NRI Tahun 1945 tegas menentukan bahwa hak

44 Sebagai contoh Ir. Joko Widodo selaku Presiden RI 2014-2019 sering disebut oleh Ketua Umum Partai Demokrasi Indonesia Perjuangan (PDIP) sebagai 'petugas partai' yang harus mengikuti instruksi ketua umum partai pengusungnya. Lebih lanjut lihat Tirto.Id, "Mengapa Megawati Terus Mengatakan Jokowi Petugas Partai”, https: / / tirto.id/mengapa-megawatiterus-mengatakan-jokowi-petugas-partai-cCXi, 9/1/2018, akses 5/2/2020. 
untuk kemerdekaan pikiran dan hati nurani merupakan hak asasi manusia yang tidak dapat dikurangi dalam keadaan apa pun. ${ }^{45}$

Dengan demikian, gagasan pencalonan Presiden dan Wakil Presiden dengan jalur perseorangan ini perlu diupayakan. Hal ini memang tidak berarti bahwa pencalonan melalui jalur partai politik tidak sejalan dengan prinsip negara hukum dan demokrasi dalam aspek jaminan hak konstitusional warga negara di bidang politik. Namun, dengan diakomodasinya mekanisme tersebut, kesempatan bagi setiap warga negara untuk menjadi calon Presiden dan Wakil Presiden menjadi terbuka lebar, dan warga negara yang hendak menyalurkan hak pilihnya juga tidak terbatas pada calon yang disediakan dari jalur partai politik.

\section{Aktualisasi Diri Warga Negara dalam Kehidupan Politik secara Mandiri}

Sebagaimana disinggung sebelumnya, hak politik merupakan hak yang tidak boleh diintervensi oleh negara. Hal ini berkaitan dengan jaminan terhadap kebebasan warga negara dalam menyalurkan aspirasi politiknya. Di dalam negara hukum yang demokratis, kesempatan warga negara untuk berpartisipasi dalam aktivitas pemerintahan baik secara langsung atau tidak tentu harus terbuka lebar. Karena itu, negara perlu memberi jaminan terhadap setiap warga negara agar dapat mengakses kesempatan tersebut. Salah satu bentuk jaminannya adalah memastikan tidak ada prosedur yang menghambat, terlebih lagi prosedur tersebut menimbulkan keterpaksaan dan ketidakmandirian warga negara dalam berpolitik.

Aktivitas mengaktualisasikan diri dalam kehidupan politik ini biasa disebut dengan partisipasi politik. Dalam literatur ilmu politik, studi mengenai partisipasi politik ini awal mulanya hanya difokuskan pada partai politik, namun seiring dengan perkembangan demokrasi justru semakin banyak bermunculan kelompok masyarakat (non partai politik) yang ingin ikut serta dalam proses politik. ${ }^{46}$ Ada

45 Lihat Pasal 28H ayat (1) Undang-Undang Dasar Negara Republik Indonesia Tahun 1945.

46 Budiarjo, Dasar-Dasar Ilmu Politik, hlm. 367. 
yang mengatakan bahwa kelompok-kelompok ini muncul lantaran kekecewaan masyarakat terhadap kinerja partai politik yang cenderung memusatkan perhatian pada satu masalah tertentu (single issue). ${ }^{47}$

Kini kondisi partai politik terlihat semakin pragmatis, hanya menampakkan ambisi terhadap kekuasaan, mengedepankan popularitas dan perolehan suara dalam pemilu, ${ }^{48}$ namun nihil terhadap isu-isu yang demikian penting dalam proses pembangunan nasional. Orientasi parpol yang sekadar meraih kekuasaan ini juga tidak jarang hanya dimanfaatkan untuk mengendalikan sektor-sektor strategis negara guna menghidupi keberlanjutan organisasi politik (parpol). ${ }^{49}$ Karena itu, parpol biasa disebut sebagai organisasi politik yang tidak mandiri, lantaran hanya menggantungkan keberlanjutan organisasinya pada kekuasaan. Fenomena itu kemudian memicu munculnya gerakan/kelompok masyarakat sebagai alternatif perjuangan politik selain melalui partai politik.

Pada dasarnya yang dimaksud dengan partisipasi politik sebagaimana terjadi di negara Barat hanya terbatas pada kegiatan sukarela saja. ${ }^{50}$ Partisipasi politik melalui partai politik memang masih dapat

47 Budiarjo, Dasar-Dasar Ilmu Politik, hlm. 367.

48 Menurut Direktur Pusat Kajian Politik (Puskapol) FISIP UI, demokrasi pada akhirnya hanya milik elite (parpol) dan bukan milik masyarakat, sehingga proses pencalonan Presiden dan Wakil Presiden (terutama penentuan cawapres) pada pemilu 2019 tidak pernah diketahui masyarakat. Pihak yang memiliki otoritas menentukan cawapres bukan lagi rakyat, melainkan hanya segelintir elite parpol. Lebih lanjut lihat Kompas.Com, "Kedua Bakal Capres Dinilai Beri Pendidikan Politik yang Buruk", https: / / nasional.kompas.com/read/2018/08/13/11354381/kedua-bakal-capresdinilai-beri-pendidikan-politik-yang-buruk, 12/8/2018, akses 5/2/2020.

49 Pernyataan ini dapat dibuktikan dengan maraknya fenomena "politik balas budi”, yang dilakukan dengan cara pemberian reward dari parpol peraih kekuasaan kepada parpol-parpol atau pihak-pihak yang mendukung/ mengantarkan pada pencapaian kekuasaan. Bentuk reward itu misalnya, kader-kader parpol pendukung ditunjuk untuk menduduki jabatan-jabatan pemerintahan tertentu. Biasanya, jabatan-jabatan yang diberikan ialah jabatan kementerian, kepengurusan BUMN (Direksi dan Komisaris).

50 Yang dimaksud kegiatan sukarela ini ialah aktivitas tanpa paksaan atau tekanan dari siapapun. Tokoh yang memiliki pandangan demikian di antaranya, Herbert McClosky, Gabriel Almond, Norman H. Nie, dan 
dikualifikasikan sebagai bentuk partisipasi secara sukarela, karena tidak ada paksaan untuk memasuki partai politik. ${ }^{51}$ Namun demikian, faktanya hampir sebagian besar jabatan pemerintahan di Indonesia hanya dapat diisi oleh kader partai politik dan/atau diusulkan oleh partai politik..$^{52}$ Mekanisme ini bermasalah dari sisi metode partisipasi politik, karena prinsip dasarnya adalah setiap orang berhak untuk mengaktualisasikan diri secara mandiri dalam kehidupan politik. Namun partisipasi politik warga negara dapat terhambat lantaran statusnya bukan sebagai anggota parpol. Seharusnya, meskipun bukan merupakan anggota partai politik atau didukung (diusulkan) oleh partai politik untuk menduduki jabatan pemerintahan, ia tetap berhak dijamin hak partisipasi politiknya.

Selain itu, ketersediaan calon Presiden dan Wakil Presiden yang hanya dari kalangan parpol, ${ }^{53}$ juga telah mereduksi kesempatan partisipasi politik warga negara yang memiliki hak pilih. Ketika partisipasi politik juga mencakup aktivitas ikut serta dalam pemilihan umum, maka kesempatan warga negara yang berminat menyalurkan aspirasi politik melalui orang yang bukan dari kalangan parpol tentu akan hilang. Warga negara terpaksa untuk memilih di antara calon yang sama-sama merupakan kader parpol atau setidak-tidaknya memiliki afiliasi dengan parpol. Karena itu, tidak heran apabila partisipasi pemilih dalam pemilu Presiden dan Wakil Presiden sering kali rendah.

Dengan demikian, gagasan pencalonan Presiden dan Wakil Presiden melalui jalur perseorangan ini menjadi penting untuk

Sidney Verba. Budiarjo, Dasar-dasar Ilmu Politik, hlm. 370.

51 Pasal 1 angka 1 Undang-Undang Nomor 2 Tahun 2008 jo. Undang-Undang Nomor 2 Tahun 2011 tentang Partai Politik: "Partai Politik adalah organisasi yang bersifat nasional dan dibentuk oleh sekelompok warga negara Indonesia secara sukarela...”.

52 Jabatan pemerintahan yang hanya dapat diisi oleh kader partai politik adalah jabatan anggota Dewan Perwakilan Rakyat/Dewan Perwakilan Rakyat Daerah; Jabatan pemerintahan yang hanya dapat diisi oleh kader partai politik atau yang diusulkan partai politik adalah jabatan Presiden dan Wakil Presiden.

53 Kader parpol atau pasangan yang diusulkan oleh parpol (memiliki afiliasi dengan parpol). 
mengakomodasi partisipasi politik warga negara dari kalangan nonparpol yang berminat mencalonkan diri sebagai pasangan calon Presiden dan Wakil Presiden. Selain itu, gagasan ini juga untuk mengakomodasi partisipasi politik warga negara yang tidak berminat menyalurkan aspirasi politiknya melalui parpol. Melalui mekanisme ini warga negara benar-benar dapat mengaktualisasikan dirinya dalam kehidupan politik secara mandiri.

\section{Rekrutmen Politik yang Bersifat Terbuka untuk Mengisi Posisi-posisi Politik yang Penting dalam Proses Penyelenggaraan Negara}

Salah satu indikator negara hukum yang demokratis ialah penyelenggaraan pemerintahan negara berdasarkan hukum yang memperhatikan substansi demokrasi. Konsekuensinya, segala prosedur dalam penyelenggaraan pemerintahan termasuk pengisian jabatan harus diatur oleh hukum (peraturan perundang-undangan) dan dilaksanakan berdasarkan prinsip-prinsip yang demokratis, seperti partisipatif, transparan, aksesibel, dan akuntabel. Salah satu posisi penting dalam proses penyelenggaraan negara yang harus diperhatikan betul pengisian jabatannya adalah, Presiden dan Wakil Presiden. Namun demikian, masih terdapat prosedur pengisian jabatan Presiden dan Wakil Presiden di Indonesia yang belum sesuai dengan prinsip negara hukum yang demokratis.

Secara normatif, satu-satunya pihak yang memainkan peran dalam menyediakan untuk mengisi jabatan Presiden dan Wakil Presiden di Indonesia adalah parpol. ${ }^{54}$ Secara lebih teknis, peran parpol dalam hal tersebut dilaksanakan melalui fungsi rekrutmen politik. $^{55}$ Khusus untuk rekrutmen bakal calon Presiden dan Wakil Presiden, undang-undang mengatur agar dilakukan secara demokratis dan terbuka sesuai dengan Anggaran Dasar (AD) dan Anggaran Rumah Tangga (ART) parpol, serta peraturan perundang-

54 Pasal 6A ayat (2) Undang-Undang Dasar Negara Republik Indonesia Tahun 1945.

55 Pasal 11 ayat (1) huruf e Undang-Undang Nomor 2 Tahun 2008 tentang Partai Politik. 
undangan. ${ }^{56}$ Namun sangat disayangkan, ketentuan tersebut tidak terlaksana secara konsekuen. Hal tersebut dapat dinilai dari dua dimensi, pertama, dari dimensi normatif ketentuan tersebut cenderung memberi peluang yang sangat besar kepada parpol untuk mengatur prosedur rekrutmen politik ini, kedua,dari dimensi empiris ketentuan ini ternyata sangat mudah dan sering disimpangi lantaran besarnya otonomi parpol dalam melaksanakan proses rekrutmen bakal calon.

Prinsip demokratis dan terbuka dalam proses rekrutmen bakal calon Presiden dan Wakil Presiden ini sering tidak berjalan efektif. Hal ini dikarenakan, undang-undang menyerahkan teknis pelaksanaannya pada AD dan ART parpol, sementara setiap parpol memiliki otoritas untuk mengatur prosedur rekrutmen tersebut dalam AD dan ART masing-masing. Karena itu, indikator "terbuka dan demokratis" parpol menjadi tidak seragam. Bahkan, prinsip demokratis dan terbuka tersebut juga sering disimpangi, lantaran ujung dari proses rekrutmen ini adalah keputusan pengurus parpol, tanpa melibatkan anggota parpol bahkan masyarakat luas. ${ }^{57}$ Maka, menjadi sangat lumrah apabila penetapan bakal calon berada pada otoritas sikap dan keputusan para petinggi partai.

Dalam praktiknya, rekrutmen secara terbuka ini memang sempat dilakukan oleh beberapa parpol, misalnya Partai Golkar pada $2004^{58}$ dan Partai Demokrat pada $2013 .{ }^{59}$ Hanya saja, rekrutmen tersebut, yang dilakukan melalui konvensi, ternyata tidak efektif dikarenakan tidak mengikat seluruh parpol, bahkan hasilnya pun tidak direalisasikan secara konsekuen. ${ }^{60}$ Atas tidak efektifnya

56 Pasal 29 ayat (2) Undang-Undang Nomor 2 Tahun 2011 tentang Perubahan atas Undang-Undang Nomor 2 Tahun 2008 tentang Partai Politik.

57 Pasal 29 ayat (3)Undang-Undang Nomor 2 Tahun 2011 tentang Perubahan atas Undang-Undang Nomor 2 Tahun 2008 tentang Partai Politik.

58 Konvensi Partai Golkar dilakukan di dalam internal partai golkar sendiri, diikuti oleh perwakilan anggota-anggota Partai Golkar.

59 Konvensi Partai Demokrat dilakukan dengan melakukan survei elektabilitas para peserta konvensi, yang pada saat itu dimenangkan oleh Dahlan Iskan.

60 Hal ini dinilai sebagai problem demokratis Pemilu. Lihat Umbu Rauta, "Menggagas Pemilihan Presiden yang Demokratis dan Aspiratif", Jurnal Konstitusi, 11, 3, (2014) hlm. 608. 
ketentuan yang diatur dalam Undang-Undang Nomor 2 Tahun 2008 jo. Undang-Undang Nomor 2 Tahun 2011 tentang Partai Politik ini berdampak pada penentuan bakal calon Presiden dan Wakil Presiden secara elitis. Artinya, pihak yang memainkan peran dalam penentuan bakal calon hanya para elite-elite parpol, khususnya pimpinan parpol. Pada penentuan pasangan calon Presiden dan Wakil Presiden untuk pemilu 2019, hal demikian sangat kentara.

Rekrutmen bakal calon Presiden dan Wakil Presiden untuk pemilu 2019 dapat dipastikan tidak dilakukan secara demokratis dan terbuka. Pada saat itu, yang menjadi teka-teki memang bukan pada siapa calon Presidennya, melainkan Wakilnya. Hingga menjelang penutupan pendaftaran, calon Wakil Presiden di antara masing-masing poros koalisi masih menjadi teka-teki. Sedari awal proses pencalonan Wakil Presiden tidak ada satupun prosedur yang dilakukan oleh parpol untuk melibatkan masyarakat kecuali berbagai survei elektabilitas yang dilakukan lembaga-lembaga survei. Bahkan, para elite partai masih melakukan rapat secara tertutup menjelang penutupan pendaftaran bakal calon untuk menentukan sosok calon Wakil Presiden yang akan mendampingi masing-masing calon Presiden. ${ }^{61}$ Dengan fenomena ini, dapat dinyatakan bahwa proses rekrutmen bakal calon Wakil Presiden untuk Pemilu 2019 nihil partisipasi rakyat.

Berkaca pada uraian tersebut, rekrutmen bakal calon Presiden

61 Sejumlah pengamat dan akademisi memaklumi fenomena ini dikarenakan dinamika politik yang lazim terjadi. Mengingat prosedur pengusulan pasangan calon Presiden dan Wakil Presiden di Indonesia terhalang ketentuan Presidential Threshold, maka parpol yang tidak mencapai ambang batas harus membentuk koalisi bersama parpol lain agar dapat mengusung pasangan calon. Sedangkan model koalisi yang sering dianut parpol-parpol di Indonesia bukan "koalisi ideologis" yang memiliki soliditas paling tinggi lantaran terjadi atas dasar kesamaan ideologi. Parpol-parpol di Indonesia lebih menganut "koalisi strategis" dan "koalisi pragmatis". Koalisi strategis terjadi atas dasar kesamaan calon Presiden/Wakil Presiden yang mereka (parpol) jagokan, sementara koalisi pragmatis soliditasnya paling lemah karena terjadi atas dasar kesamaan isu yang mereka usung. Denny Indrayana, "Mengacau Koalisi Menuai Oposisi", Seputar Indonesia, 5/3/2011, yang kembali dibukukan dalam Denny Indrayana, Indonesia Optimis (Jakarta: PT. Bhuana Ilmu Populer, 2011), hlm. 99-100. 
dan Wakil Presiden yang dilakukan melalui parpol cenderung elitis. Apabila hal demikian terjadi terus menerus, maka dikhawatirkan semakin menimbulkan oligarki. Bahkan berbagai sektor urusan negara berpotensi hanya dikendalikan oleh elit partai politik. Kekhawatiran tersebut seirama dengan pernyataan Noam Chomsky yang memadukan pandangan Walter Lippmann, bahwa peranan publik dalam "teori demokrasi" modern sekadar "kawanan yang kebingungan", ia hanya sebagai penonton, dan bukan partisipan. ${ }^{62}$ Rakyat dianggap muncul setiap beberapa tahununtuk menyeleksi wakil-wakilnya di sektor-sektor dominan lewat yang disebut 'pemilihan'.

Oleh karena itu, pembenahan proses rekrutmen politik di Indonesia merupakan hal yang penting dan mendesak. Rekrutmen politik dalam negara hukum yang demokratis harus melibatkan masyarakat secara partisipatif, sehingga prinsip demokrasi benarbenar terealisasikan. Gagasan pencalonan Presiden dan Wakil Presiden melalui jalur perseorangan menjadi relevan untuk diimplementasikan. Hal ini dikarenakan, rekrutmen bakal calon melalui jalur perseorangan sangat memungkinkan dilakukan secara demokratis dan terbuka melibatkan masyarakat sipil secara luas. Mekanisme ini harus diatur dalam undang-undang tentang kepemiluan.

\section{Kekuasaan Pemerintahan di Tangan Rakyat yang Dijalankan Berdasarkan Konstitusi}

Kolaborasi antara gagasan demokrasi dengan negara hukum ini dapat dinyatakan telah merasuk dalam konstruksi UUD NRI Tahun 1945. Secara normatif, hal itu telah dituangkan dalam Pasal 1 ayat (2) dan Pasal 1 ayat (3) UUD NRI Tahun 1945, yang berbunyi "Kedaulatan berada di tangan rakyat dan dilaksanakan menurut UndangUndang Dasar", dan "Negara Indonesia adalah negara hukum". Pada dasarnya, cukup melalui Pasal 1 ayat (2) UUD NRI Tahun 1945 tersebut sudah mencerminkan adanya dua prinsip bernegara yang dianut di Indonesia, yaitu kedaulatan rakyat (demokrasi) dan negara

62 Chomsky, How The World, hlm. 189. 
hukum. Namun kemudian, Pasal 1 ayat (3) UUD NRI Tahun 1945 lebih mempertegas komitmen bangsa Indonesia dalam mendirikan negara Republik Indonesia yang juga berdasarkan prinsip negara hukum.

Pengisian jabatan Presiden dan Wakil Presiden memilikipertalian dengan prinsip kedaulatan rakyat (demokrasi) dan negara hukum. Sebab, pengisian jabatan Presiden dan Wakil Presiden ini identik dengan tahapan pembentukan pemerintahan negara. Sebagaimana diketahui, di antara unsur negara hukum adalah pemerintahan berdasar undang-undang (hukum), pemerintah menghormati hakhak individu, peradilan yang bebas (independen) dan imparsial, asas legalitas. Kendati demikian, negara hukum tidak sebatas prinsip dalam pelaksanaan pemerintahan, melainkan juga termasuk prinsip pada tahapan pembentukan pemerintahan, khususnya pengisian jabatan Presiden dan Wakil Presiden ini. Hal ini sebagai penyeimbang prinsip demokrasi yang lebih sering digunakan sebagai dasar dalam pembentukan pemerintahan.

Konstitusi merupakan suatu kerangka dasar kehidupan politik pemerintahan yang konstitusional, dengan karakteristik di antaranya memperluas partisipasi politik, memberi kekuasaan legislatif pada rakyat, menolak pemerintahan otoriter. ${ }^{63}$ Persoalan yang kemudian timbul adalah, sejauh mana hukum (Konstitusi) dapat menjangkau (mengatur) tahapan pembentukan pemerintahan, khususnya mengenai pengisian jabatan Presiden dan Wakil Presiden, dan sejauh mana pula hukum dapat mengakomodasi pemenuhan hak-hak warga negara yang berdaulat dalam tahapan pembentukan pemerintahan. Untuk saat ini, UUD NRI Tahun 1945 mengatur pengisian jabatan Presiden dan Wakil Presiden secara cukup rinci, sebagaimana ditentukan dalam Pasal 6A.

Pada satu sisi, Konstitusi mengakomodasi hak-hak warga negara dalam proses pengisian jabatan Presiden dan Wakil Presiden. Bentuk akomodasi tersebut seperti yang telah tertuang dalam Pasal 6A ayat

63 Demikian menurut Adnan Buyung Nasution, sebagaimana dikutip M. Agus Santoso, "Perkembangan Konstitusi di Indonesia", Jurnal Yustisia, 2, 3 (2013), hlm. 118. 
(1), Pasal 6A ayat (2), Pasal 27 ayat (1), dan Pasal 28D ayat (3) UUD NRI Tahun 1945. Namun demikian, terdapat inkonsistensi di antara ketentuan tersebut, khususnya akibat Pasal 6A ayat (2) yang mengatur parpol atau gabungan parpol sebagai satu-satunya pihak yang dapat mengusulkan pasangan calon Presiden dan Wakil Presiden. Jika prosedur pengusulan melalui parpol disebut sebagai metode seleksi bakal calon, tentu hal ini tidak selaras dengan prinsip demokrasi. Demokrasi itu sebagai sebuah sistem yang memungkinkan semua warga berpartisipasi dalam memilih di antara calon dan kelompok yang bersaing, yang mengklaim paling mewakili kepentingan dan nilai mereka. ${ }^{64}$

Meski parpol dipahami sebagai organisasi politik yang dibentuk oleh masyarakat/rakyat untuk mewakili kepentingan rakyat sebagai pelaksanaan prinsip demokrasi, perkembangannya justru tidaklah demikian. Pemahaman tersebut mustahil dapat terealisasi dengan sempurna dikarenakan beberapa kendala. Pertama, kebutuhan finansial untuk mendirikan parpol yang mampu memenuhi kualifikasi sebagai peserta pemilu tentu tidak kecil, sehingga hanya parpol yang dibentuk oleh warga negara yang memiliki kekayaan atau mendapat bantuan dana dari pengusaha-pengusaha besar saja yang mampu eksis dalam kontestasi pemilu. Kedua, parpol cenderung tidak merepresentasikan seluruh rakyat, tetapi hanya kelompok atau konstituennya. Dengan demikian, esensi demokrasi yang dimaksudkan untuk menjamin terwujudnya pemerintahan rakyat, akan sulit terwujud apabila legitimasi untuk mengusulkan pasangan calon Presiden dan Wakil Presiden hanya merupakan hak parpol atau gabungan parpol.

Meski pencalonan Presiden dan Wakil Presiden melalui jalur parpol juga relevan dengan prinsip negara hukum dan demokrasi, namun Konstitusi dipandang perlu untuk didesain secara lebih akomodatif terhadap peluang jalur perseorangan dalam proses pengisian jabatan Presiden dan Wakil Presiden. Hal ini sebagai

64 Hamdan Kurniawan, "Eksistensi Calon Perseorangan dan Problem Seleksi Kandidat di Tubuh Partai Politik dalam Pemilukada”, Jurnal Konstitusi Universitas Janabadra, 1, 1 (2012), hlm. 5. 
bentuk komitmen dalam mengimplementasikan prinsip negara hukum dan demokrasi. Ketika prinsip negara hukum dan demokrasi memiliki kriteria "pemerintahan rakyat yang dijalankan berdasarkan konstitusi”, maka sedapat mungkin ketentuan dalam konstitusi tidak mereduksi kedaulatan rakyat yang merupakan jantungnya sistem pemerintahan demokrasi. Pembentukan pemerintahan yang dilakukan pada saat pengisian jabatan Presiden dan Wakil Presiden harus lebih membuka peluang dan kesempatan kepada rakyat untuk merealisasikan kedaulatannya.

Ringkasnya, kesesuaian antara gagasan pencalonan pasangan calon Presiden dan Wakil Presiden melalui jalur perseorangan dapat dilihat dalam Tabel 1 .

Tabel 1. Relevansi Prinsip Negara Hukum dan Demokrasi dengan Gagasan Pengusulan Calon Presiden dan Wakil Presiden Perseorangan

\begin{tabular}{|c|c|}
\hline $\begin{array}{l}\text { Elemen Prinsip Negara Hukum } \\
\text { dan Demokrasi }\end{array}$ & Keunggulan Calon Perseorangan \\
\hline $\begin{array}{l}\text { Jaminan hak konstitusional warga } \\
\text { negara di bidang politik }\end{array}$ & $\begin{array}{l}\text { Warga negara tidak terpaksa } \\
\text { menyalurkan hak politiknya dengan/ } \\
\text { atau melalui parpol atau setidak- } \\
\text { tidaknya berafiliasi dengan parpol. }\end{array}$ \\
\hline $\begin{array}{l}\text { Aktualisasi diri warga negara dalam } \\
\text { kehidupan politik secara mandiri (tanpa } \\
\text { digerakkan atau tanpa paksaan) }\end{array}$ & $\begin{array}{l}\text { Calon perseorangan/independen } \\
\text { sebagai bentuk aktualisasi mandiri } \\
\text { dalam kehidupan politik. }\end{array}$ \\
\hline $\begin{array}{l}\text { Jaminan rekrutmen politik untuk } \\
\text { mengisi posisi-posisi politik } \\
\text { yang penting di dalam proses } \\
\text { penyelenggaraan negara secara terbuka }\end{array}$ & $\begin{array}{l}\text { Prosedur pencalonanmelalui jalur } \\
\text { perseorangan memungkinkan } \\
\text { rekrutmen secara terbuka dengan } \\
\text { syarat-syarat tertentu yang melibatkan } \\
\text { masyarakat luas. }\end{array}$ \\
\hline $\begin{array}{l}\text { Menjamin pemerintahan yang } \\
\text { berdasarkan konstitusi secara } \\
\text { akomodatif dan tetap teratur } \\
\text { berdasarkan hukum }\end{array}$ & $\begin{array}{l}\text { Konstitusi \& Perundang-undangan } \\
\text { yang mengakomodasi dan mengatur } \\
\text { pencalonan perseorangan sebagai } \\
\text { bentuk konsistensi terhadap asas } \\
\text { kedaulatan rakyat. }\end{array}$ \\
\hline
\end{tabular}

\section{Kesimpulan}

Gagasan pencalonan Presiden dan Wakil Presiden melalui jalur perseorangan memiliki relevansi terhadap prinsip negara hukum dan demokrasi. Relevansi ini dapat terlihat karena mekanisme pencalonan 
Presiden dan Wakil Presiden yang hanya memungkinkan diusulkan oleh parpol atau gabungan parpol (Pasal 6A ayat (2) UUD NRI Tahun 1945) justru kontradiksi dengan prinsip negara hukum yang demokratis. Asas kedaulatan rakyat dapat tereduksi, melanggengkan kekuasaan sekelompok elite partai tertentu (oligarki), menutup kesempatan warga negara non partisan, membatasi alternatif calon sehingga persaingan tidak kompetitif dan pilihan rakyat terbatas, dan mempersempit ruang partisipasi rakyat. Bahkan ketentuan Pasal 6A ayat (2) UUD NRI Tahun 1945 cenderung "memaksa" warga negara untuk berpartai politik atau setidak-tidaknya berafiliasi dengan parpol.

Gagasan ini relevan dengan prinsip negara hukum dan demokrasi. Pertama, untuk menjamin hak asasi manusia (HAM) di bidang politik. Gagasan ini untuk mengatasi pemaksaan hak politik warga negara yang tidak menaruh minat menyalurkan aspirasinya melalui parpol, atau kepada pasangan calon yang berafiliasi dengan parpol. Kedua, menjamin aktualisasi diri warga negara dalam kehidupan politik secara mandiri (tanpa digerakkan). Gagasan ini untuk mengakomodasi warga negara yang berpolitik melalui jalur perseorangan (independen), tanpa dimobilisasi parpol-parpol. Ketiga, menjamin rekrutmen politik untuk mengisi jabatan-jabatan penyelenggaran negara secara terbuka. Gagasan ini untuk menjamin keterlibatan rakyat dalam proses pengisian jabatan Presiden dan Wakil Presiden, sejak penominasian bakal calon hingga pemilihan calon. Keempat, menjamin pemerintahan yang berdasarkan konstitusi secara akomodatif dan tetap teratur berdasarkan hukum. Prinsipnya, ketentuan-ketentuan dalam konstitusi tidak boleh mereduksi kedaulatan rakyat.

\section{Daftar Pustaka}

\section{Artikel, Buku, dan Laporan}

Aisha, Mitra, Mexsasai Indra, dan Junaidi. "Gagasan Calon Perseorangan dalam Pemilihan Presiden dan Wakil Presiden dalam Sistem Ketatanegaraan Indonesia”. Http://jom.unri. 
ac.id/index.php/JOMFHUKUM/article/view/ 5524.

Asshiddiqie, Jimly. Konstitusi dan Konstitusionalisme Indonesia. Jakarta:

Sinar Grafika, cetakan ketiga, 2014.

Asshiddiqie, Jimly. Pokok-pokok Hukum Tata Negara Indonesia Pasca

Reformasi. Jakarta: PT. Bhuana Ilmu Populer, 2007.

Budiarjo, Miriam. Dasar-Dasar Ilmu Politik. Jakarta: PT Grafika Pustaka Utama, 2008.

C.S.T Kansil. Memahami Pemilihan Umum dan Referendum: Sarana Demokrasi Pancasila. Jakarta: Ind-Hill-Co, 1986.

Chomsky, Noam. How The World Works. Terjemah oleh Tia Setiadi.

Yogyakarta: PT Bentang Pustaka, cetakan ketiga, 2017.

Faiz, Pan Mohamad. "Memperkuat Prinsip Pemilu Teratur, Bebas, dan Adil Melalui Pengujian Konstitusionalitas Undang-Undang. Jurnal Konstitusi, 14, 3 (2017): 673-700. DOI: 10.31078/jk14310.

Fahmi, Khairul. "Pergeseran pembatasan Hak Pilih dalam Regulasi

Pemilu dan Pilkada", Jurnal Konstitusi, Volume 14, No. 4, (Desember 2017): 757-777. DOI: 10.31078/jk1443.

Gaffar, Afan. Politik Indonesia Transisi Menuju Demokrasi. Yogyakarta:

Pustaka Pelajar, 2001.

Hadjon, Philipus M. Perlindungan Hukum Bagi Rakyat di Indonesia. Surabaya: Bina Ilmu, 1987.

Hatta, Mohammad. Demokrasi Kita, dan Pikiran-pikiran tentang Demokrasi \& Kedaulatan Rakyat. Bandung: Sega Arsy, cetakan kedua, 2009.

Huda, Ni'matul dan Imam Nasef. Penataan Demokrasi dan Pemilu. Jakarta: Kencana, 2017.

Huda, Ni'matul. Negara Hukum, Demokrasi, dan Judicial Review. Yogyakarta, UII Press, 2005.

Indrayana, Denny. Indonesia Optimis. Jakarta: PT. Bhuana Ilmu Populer, 2011.

Istinah, Siti Rodhiyah Dwi. "Gagasan Calon Presiden dan Wakil Presiden Perseorangan dalam Rangka Peningkatan Kualitas Demokrasi di Indonesia”. Jurnal Hukum Fakultas Hukum Unissula, 28, 2 (2012): 900-28.

Kompas.Com. "Kedua Bakal Capres Dinilai Beri Pendidikan 
Politik yang Buruk”. Https://nasional.kompas.com/ $\mathrm{read} / 2018 / 08 / 13 / 11354381 /$ kedua-bakal-capres-dinilai-beripendidikan-politik-yang-buruk, 13/8/2018. Diakses 5/2/2020.

Kurniawan, Hamdan. "Eksistensi Calon Perseorangan dan Problem Seleksi Kandidat di Tubuh Partai Politik dalam Pemilukada". Jurnal Konstitusi Universitas Janabadra, 1, 1 (2012): 1-153.

Mahfud MD. Hukum dan Pilar-Pilar Demokrasi. Yogyakarta: Gama Media, 1999.

Muntoha. Negara Hukum Indonesia Pasca Perubahan UUD 1945. Bantul: Kaukaba, 2013.

Prodjodikoro, Wirjono. Asas-Asas Ilmu Negara dan Politik. Jakarta: PT. Eresco, 1981.

Rauta, Umbu. "Menggagas Pemilihan Presiden yang Demokratis dan Aspiratif". Jurnal Konstitusi, 11, 3, (2014): 600-616.

Ridwan HR. Hukum Administrasi Negara. Jakarta: Rajawali Pers, 2011.

Riyadi, Eko. Hak Asasi Manusia: Perspektif Internasional, Regional, dan Nasional. Depok: Rajawali Pers, 2018.

Riyadi, Eko. "Politik Hukum Hak Asasi Manusia: Kajian terhadap Undang-Undang Nomor 7 Tahun 2004 tentang Air”. Dalam Mengurai Kompleksitas Hak Asasi Manusia, diedit oleh Eko Riyadi dan Supriyanto Abdi, 239-253. Yogyakarta: PUSHAM UII, 2007. Safa'at, Muchammad Ali. "Klasifikasi Negara Demokrasi Menurut Arend Lijphart”. Http:/ / safaat.lecture.ub.ac.id/files/2012 / 04 / Klasifikasi-Negara-Demokrasi-Menurut-Arend-Lijphart.pdf, 21/4/2012. Diakses 15/6/2020.

Santoso, M. Agus. "Perkembangan Konstitusi di Indonesia". Jurnal Yustisia, 2, 3 (2013): 118-126. DOI: 10.20961/yustisia. v2i3.10168.

Smith, Rhona K.M., dkk. Hukum Hak Asasi Manusia, diedit oleh Knut D. Asplund, Suparman Marzuki, dan Eko Riyadi. Yogyakarta: PUSHAM UII, 2008.

Tirto.Id. "Mengapa Megawati Terus Mengatakan Jokowi Petugas Partai”. Https://tirto.id/mengapa-megawati-terusmengatakan-jokowi-petugas-partai-cCXi, 9/1/2018. Diakses 
$5 / 2 / 2020$.

\section{Peraturan dan Putusan Hukum}

Republik Indonesia. Undang-Undang Dasar Negara Republik Indonesia Tahun 1945.

Republik Indonesia. Undang-Undang Nomor 2 Tahun 2011 tentang

Perubahan atas Undang-Undang Nomor 2 Tahun 2008 tentang

Partai Politik. Lembaran Negara Tahun 2011 Nomor 8, Tambahan Lembaran Nomor 5189.

Republik Indonesia, Mahkamah Konstitusi. Putusan Nomor 011-

017/PUU-I/2003, perkara Pengujian Undang-Undang Republik Indonesia Nomor 12 Tahun 2003 tentang Pemilihan Umum Anggota Dewan Perwakilan Rakyat, Dewan Perwakilan Daerah, dan Dewan Perwakilan Rakyat Daerah terhadap UndangUndang Dasar Negara Republik Indonesia Tahun 1945.

Republik Indonesia, Mahkamah Konstitusi. Putusan Nomor 007/ PUU-II/2004, perkara Pengujian Undang-undang Republik Indonesia Nomor 23 Tahun 2003 tentang Pemilihan Umum Presiden dan Wakil Presiden terhadap Undang-Undang Dasar Negara Republik Indonesia Tahun 1945.

Republik Indonesia, Mahkamah Konstitusi. Putusan Nomor 054/ PUU-II/2004, perkara Pengujian Undang-undang Republik Indonesia Nomor 23 Tahun 2003 tentang Pemilihan Umum Presiden dan Wakil Presiden terhadap Undang-Undang Dasar Negara Republik Indonesia Tahun 1945.

Republik Indonesia, Mahkamah Konstitusi. Putusan Nomor 057/ PUU-II/2004, perkara Pengujian Undang-undang Republik Indonesia Nomor 23 Tahun 2003 tentang Pemilihan Umum Presiden dan Wakil Presiden terhadap Undang-Undang Dasar Negara Republik Indonesia Tahun 1945.

Republik Indonesia, Mahkamah Konstitusi. Putusan Nomor 5/PUUV/2007, perkara pengujian Undang-undang Republik Indonesia Nomor 32 Tahun 2004 tentang Pemerintahan Daerah terhadap Undang-Undang Dasar Negara Republik Indonesia Tahun 1945. 
Republik Indonesia, Mahkamah Konstitusi. Putusan Nomor 1417/PUU-V/2007, perkara Pengujian Undang-Undang Nomor 23 Tahun 2003 tentang Pemilihan Umum Presiden dan Wakil Presiden, Undang-Undang Nomor 24 Tahun 2003 tentang Mahkamah Konstitusi, Undang-Undang Nomor 5 Tahun 2004 tentang Perubahan Atas Undang-Undang Nomor 14 Tahun 1985 tentang Mahkamah Agung, Undang-Undang Nomor 32 Tahun 2004 tentang Pemerintahan Daerah, dan Undang-Undang Nomor 15 Tahun 2006 tentang Badan Pemeriksa Keuangan terhadap Undang-Undang Dasar Negara Republik Indonesia Tahun 1945.

Republik Indonesia, Mahkamah Konstitusi. Putusan Nomor 51-5259/PUU-VI/2008, perkara Pengujian Undang-Undang Nomor 42 Tahun 2008 tentang Pemilihan Umum Presiden dan Wakil Presiden terhadap Undang-Undang Dasar Negara Republik Indonesia Tahun 1945.

Republik Indonesia, Mahkamah Konstitusi. Putusan Nomor 56/ PUU-VI/2008, perkara Pengujian Undang-Undang Nomor 42 Tahun 2008 tentang Pemilihan Umum Presiden dan Wakil Presiden terhadap Undang-Undang Dasar Negara Republik Indonesia Tahun 1945.

Republik Indonesia, Mahkamah Konstitusi. Putusan Nomor 4/ PUUVII/2009, perkara Pengujian Undang-Undang Nomor 10 Tahun 2008 tentang Pemilihan Umum Anggota Dewan Perwakilan Rakyat, Dewan Perwakilan Daerah, dan Dewan Perwakilan Rakyat Daerah dan Undang-Undang Nomor 12 Tahun 2008 tentang Perubahan Kedua Atas Undang-Undang Nomor 32 Tahun 2004 tentang Pemerintahan Daerah terhadap UndangUndang Dasar Negara Republik Indonesia Tahun 1945.

Republik Indonesia, Mahkamah Konstitusi. Putusan Nomor 42/ PUU-XIII/2015, perkara Pengujian Undang-Undang Nomor 8 Tahun 2015 tentang Perubahan atas Undang-Undang Nomor 1 Tahun 2015 tentang Penetapan Peraturan Pemerintah Pengganti Undang-Undang Nomor 1 Tahun 2014 tentang Pemilihan Gubernur, Bupati, dan Walikota Menjadi Undang-Undang 
Relevansi Gagasan Pencalonan Presiden dan Wakil Presiden terhadap Undang-Undang Dasar Negara Republik Indonesia Tahun 1945. 